\section{Kepuasan Konsumen Sunyi House of Coffee and Hope}

\author{
Berliana Adinda Lorenssa ${ }^{1}$, Miguna Astuti $^{2}$, Renny Husniati ${ }^{3}$ \\ Fakultas Ekonomi dan Bisnis Universitas Pembangunan Nasional Veteran Jakarta \\ Email: berlianalorenssa01@gmail.com ${ }^{1}$, miguna.astuti@upnvj.ac.id ${ }^{2}$, \\ renyhusniati@gmail.com ${ }^{3}$
}

\begin{abstract}
In this research there is a quantitative descriptive methods were used with respondents, namely consumers of Sunyi House of Coffee and Hope. This coffee shop has employees with disabilities. In this research aims to determine the condition of consumer satisfaction Sunyi House of Coffee and Hope is influenced by the service quality, location and facilities. The population in this study are customers of Sunyi House of Coffee and Hope. Samples taken as many as 100 respondents by random sampling method. Data collection was done through the distribution of questionnaires with descriptive data analysis techniques. The results of the study stated that 1). Has led to customer satisfaction Sunyi House of Coffee and Hope, 2). Service quality has been done well, 3). The location offered received very high attention, 4). The facilities provided are quite good.
\end{abstract}

Keywords : Service Quality, Location, Facilities, Customer Satisfaction, Coffee Shop

\begin{abstract}
ABSTRAK
Pada penelitian ini digunakan metode deskriptif kuantitatif dengan responden yaitu konsumen Sunyi House of Coffee and Hope. Coffee shop ini memiliki karyawan penyandang disabilitas. Penelitian ini memiliki tujuan untuk mengetahui kondisi kepuasan konsumen Sunyi House of Coffee and Hope dipengaruhi oleh kualitas pelayanan, lokasi dan fasilitas. Populasi dalam penelitian ini adalah pelanggan Sunyi House of Coffee and Hope. Sampel yang diambil sebanyak 100 responden dengan metode random sampling. Pengumpulan data melalui penyebaran kuesioner dengan teknik analisis data deskriptif. Hasil penelitian menyatakan bahwa 1). Telah memunculkan kepuasan kepuasan konsumen Sunyi House of Coffee and Hope, 2). Kualitas pelayanan telah dilakukan dengan baik, 3). Lokasi yang ditawarkan mendapat perhatian yang sangat tinggi, 4). Fasilitas yang disediakan sudah cukup baik.
\end{abstract}

Kata Kunci : Kualitas Pelayanan, Lokasi, Fasilitas, Kepuasan Konsumen, Coffee Shop

\title{
PENDAHULUAN
}

Pada Era Globalisasi saat ini telah membentuk sebuah generasi milenial, sekitar 49\% penduduk Indonesia berasal dari generasi milenial dimana generasi milenial tersebut dipengaruhi oleh adanya internet dalam kesehariannya (Soebiakto, 2018). Pada tahun 2015 hingga 2019 rencana pemerintah dalam strategi produksi kopi mengalami peningkatan di beberapa daerah di Indonesia (Kementan, 2014). Untuk saat ini masyarakat Indonesia lebih sering menghabiskan waktu luangnya untuk bersosialisasi dengan mengunjungi pusat pembelanjaan atau berjalan-jalan mengunjungi tempat yang unik dengan bersantai (Utami, 2018). Berdasarkan hasil riset TOFFIN pada tahun 2019 jumlah coffee shop mengalami peningkatan di dukung oleh konsumsi kopinya juga

\section{JIMKES}

Jurnal Ilmiah Manajemen Kesatuan Vol. 8 No. 3,2020 pp. $249-260$ IBI Kesatuan
ISSN $2337-7860$ E-ISSN 2721 - 169X 
Customer

Satisfaction and

Coffee Shop

meningkat, untuk saat ini berjumlah 2.950 di Indonesia. Pertumbuhan coffee shop sebesar $10 \%$ di wilayah Jakarta setiap tahunnya (Sugianto, 2019). Hal tersebut juga didukung oleh teori Rhenald Kasali yang berpendapat bahwa "meminum kopi kini bukan lagi sekedar untuk menghilangkan kantuk, tapi sebagai bagian gaya hidup, dimana coffee shop menjadi tempat berkumpul yang amat diminati" (Putri \& Suasana, 2017).

Coffee shop Sunyi House of Coffee and Hope ini rata- rata memiliki pengunjung dari kalangan remaja hingga dewasa. Selain itu, coffee shop ini memperkenalkan berbagai jenis kopi nusantara dengan harga yang terjangkau. Meski demikian data review mengenai Sunyi House of Coffee and Hope yang dapat dilihat pada tabel 1.

Tabel 1. Daftar Review Konsumen Sunyi House of Coffee and Hope

\begin{tabular}{lccc}
\hline \multicolumn{1}{c}{ Situs } & Puas & Kurang Puas & Total Review \\
\hline Traveloka & 1 & 3 & 4 \\
\hline Pergi Kuliner & 1 & 10 & 11 \\
\hline Qraved & 0 & 1 & 1 \\
\hline Zomato & 59 & 55 & 114 \\
\hline Google & 260 & 115 & 375 \\
\hline \multicolumn{1}{c}{ Total Kepuasan } & 321 & 184 & 505
\end{tabular}

Sumber: data diolah Traveloka, Pergi Kuliner, Qraved, Zomato dan Google

Berdasarkan pada tabel 1. dapat disimpulkan bahwa dari total review kepuasan konsumen sebesar 505, terdapat 321 review (64\%) merasa puas dan 184 review (36\%) merasa kurang puas. Persentase tersebut didukung oleh teori (Kotler, 2007).yg menyatakan bahwa jika ketidakpuasan pelanggan menunjukkan minimal sebesar $25 \%$ dari keseluruhan dapat diartikan bahwa Sunyi House of Coffee and Hope memiliki permasalahan mengenai kepuasan konsumen.

Dari 36\% yang merasa belum puas mengenai Sunyi House of Coffee and Hope sebanyak $15 \%$ mengeluh mengenai lokasi yaitu terkait tata letak yang kurang strategis dan parkiran yang kurang luas. Sebelumnya telah banyak pula penelitian terdahulu terkait variabel lokasi serta kepuasan konsumen (Adhistyo W \& Nugraheni, 2020; Limbeng et al., 2020; Mahyuddin \& Juraidah, 2017; Sofia et al., 2019). Lalu, sebanyak 12\% mengeluh mengenai fasilitas yaitu terkait tempat yang kurang memadai, suasana dan pencahayaan yang kurang, dan desain coffee shop yang kurang menarik. Penelitian yang terkait terdahulu terkait fasilitas serta kepuasan konsumen juga telah dilakukan oleh penelitian terdahulu (Adhistyo W \& Nugraheni, 2020; Pantilu et al., 2018; Winarno et al., 2018). Kemudian sebanyak $9 \%$ pelanggan mengeluh mengenai durasi melayani yang lama dan pengaturan meja dan kursi yang kurang baik. Sehingga pada saat proses pelayanan antara pelanggan dan karwayan coffee shop yang juga penyandang disabilitas mengalami kesulitan. Dan telah banyak pula penelitian terdahulu terkait variabel kualitas pelayanan serta kepuasan konsumen (Apriyani \& Sunarti, 2017; Asniwaty et al., 2019; Dewa, 2019; Jufriyanto, 2020; Mahyuddin \& Juraidah, 2017; Mu'tashim \& Slamet, 2020; Pantilu et al., 2018; Sofia et al., 2019; Theisen \& Metzner, 2018; Yunita, 2018). Tujuan Penelitian ini adalah untuk mengetahui kondisi kepuasan konsumen Sunyi House of Coffee and Hope termasuk di dalamnya kualitas pelayanan, lokasi dan fasilitas.

\section{METODE PENELITIAN \\ Definisi Operasional}

Definisi operasional dari variabel-variabel yang digunakan pada penelitian ini sebagai berikut:

Kepuasan Konsumen (Y). Kepuasan konsumen merupakan senang rasa baik kecewa konsumen pada saat mengonsumsi produk atau jasa sebagai hasil perbandingan dengan harapan atau ekspetasi mereka sebelum mengkonsumsi produk atau jasa dari Sunyi House of Coffee and Hope. Jawaban responden terhadap kepuasan konsumen diperoleh melalui indikator kesesuaian antara harapan dari pelayanan yang diberikan terhadap performance yang diterima. 
Kualitas Pelayanan $\left(\mathbf{X}_{\mathbf{1}}\right)$. Kualitas pelayanan, kegiatan atau tindakan usaha Sunyi House of Coffee and Hope dalam cara pemenuhan butuh dan ingin konsumennya dengan menawarkan beberapa pelayanan yang baik. Jawaban responden terhadap kualitas pelayanan diperoleh melalui indikator karyawan berpenampilan baik dan rapih, karyawan tepat dalam memberikan informasi, karyawan yang cepat tanggap dalam pelayanan, karyawan bersikap sopan pada saat melayani konsumen, dan karyawan memahami apa yang diinginkan konsumen.

Lokasi $\left(\mathbf{X}_{2}\right)$. Lokasi merupakan tempat dimana Sunyi House of Coffee and Hope beroperasi dengan melakukan kegiatan untuk menghasilkan produk atau jasa. Jawaban responden terhadap lokasi diperoleh melalui indikator akses, lalu-lintas (traffic), tempat parkir, dan lingkungan.

Fasilitas $\left(\mathbf{X}_{3}\right)$. Fasilitas merupakan sarana dan prasarana yang dapat mempermudah konsumen Sunyi House of Coffee and Hope dalam menikmati produk dan jasa yang disediakan. Jawaban responden terhadap fasilitas diperoleh melalui indikator perencanaan ruangan, pelengkapan atau peralatan, dan tata cahaya

\section{Populasi dan Sampel}

Yang menjadi target dalam penelitian ini adalah pelanggan yang pernah berkunjung di Sunyi House of Coffee and Hope. Penelitian ini meggunakan teknik pengambilan sampel probability sampling, dalam arti teknik peluang yang diberikan pada setiap anggota sama sehingga dipilih jadi anggota sampel. Sementara, random sampling menjadi metode, secara acak dipilih dengan tidak lihat dari tingkatan yang ada pada populasi tersebut (Sugiyono, 2014, hlm. 151-152). Jumlah sampel yang akan diambil dalam penelitian ini ialah menggunakan rumus Lemeshow yaitu sebesar 100 responden, hal ini dikarenakan jumlah populasi yang tidak diketahui.

\section{Jenis dan Sumber Data}

Penelitian ini menggunakan jenis data penelitian kuantitaif dan berasal dari data primer yaitu diperoleh secara langsung oleh peneliti dengan cara melakukan menyebarkan kuesioner tersebut (Sugiyono, 2014, hlm. 125). Sehingga penyebaran lewat google form untuk perolehan hasil kuesioner dalam waktu tiga minggu.

\section{Pengumpulan Data}

Pada penelitian ini data yang dikumpulkan menggunakan teknik angket atau kuesioner, dan peneliti juga menggunakan skala likert dalam pengukurannya. (Sugiyono, 2014, hlm. 93). Dalam penelitian ini menggunakan 2 (dua) skala likert yaitu:

Tabel 2. Bobot Penilaian Berdasarkan Skala Likert

\begin{tabular}{ccccc}
\hline Bobot & Penilaian & Keterangan & Penilaian & Keterangan \\
\hline 1 & STM & Sangat Tidak Memuaskan & STS & Sangat Tidak Setuju \\
\hline 2 & TM & Tidak Memuaskan & TS & Tidak Setuju \\
\hline 3 & N & Netral (Ragu-Ragu) & N & Netral (Ragu-Ragu) \\
\hline 4 & M & Memuaskan & S & Setuju \\
\hline 5 & SM & Sangat Memuaskan & SS & Sangat Setuju \\
\hline
\end{tabular}

Sumber: Sugiyono (2014, hlm. 168)

Berdasarkan tabel 2. diatas skala Likert diberikan pada setiap pernyataan yang didasarkan oleh indikator, maka tabel kisi-kisi instrumen berikut ini dapat dijelaskan.

Tabel 2. Kisi-Kisi Instrumen

\begin{tabular}{clcc}
\hline Variabel & \multicolumn{1}{c}{ Indikator } & $\begin{array}{c}\text { Butir } \\
\text { Pertanyaan }\end{array}$ & $\begin{array}{c}\text { Jumlah } \\
\text { Pertanyaan }\end{array}$ \\
\hline Kepuasan & $\begin{array}{l}\text { Kesesuaian antara harapan dari pelayanan } \\
\text { Konsumen }(\mathrm{Y})\end{array}$ & $\begin{array}{l}1,2,3,4,5,6,7 \\
\text { yang diberikan terhadap performance yang } \\
\text { diterima }\end{array}$ & $\begin{array}{c}8,9,10,11,1 \\
2\end{array}$ \\
\hline Kualitas & Karyawan berpenampilan baik dan rapih & 13,14 & 2 \\
\cline { 2 - 4 } Pelayanan $\left(\mathrm{X}_{1}\right)$ & $\begin{array}{l}\text { Karyawan tepat dalam memberikan } \\
\text { informasi }\end{array}$ & 15,16 & 2 \\
\cline { 2 - 4 } & $\begin{array}{l}\text { Karyawan yang cepat tanggap dalam } \\
\text { pelayanan }\end{array}$ & 17,18 & 2 \\
\hline
\end{tabular}


Customer

Satisfaction and

Coffee Shop

\begin{tabular}{llll}
\hline & $\begin{array}{l}\text { Karyawan bersikap sopan pada saat } \\
\text { melayani konsumen }\end{array}$ & 19.20 & 2 \\
\cline { 2 - 4 } & $\begin{array}{l}\text { Karyawan memahami apa yang diinginkan } \\
\text { konsumen }\end{array}$ & 21,22 & 2 \\
\hline Lokasi $\left(\mathrm{X}_{2}\right)$ & Akses & 23,24 & 2 \\
\cline { 2 - 4 } & Lalu - lintas (traffic) & 25,26 & 2 \\
\cline { 2 - 4 } & Tempat Parkir & 27,28 & 2 \\
\cline { 2 - 4 } & Lingkungan & 29,30 & 2 \\
\hline Fasilitas $\left(\mathrm{X}_{3}\right)$ & Perencanaan ruangan & 31,32 & 2 \\
\cline { 2 - 4 } & Perlengkapan atau peralatan & 33,34 & 2 \\
\cline { 2 - 4 } & Tata cahaya & 35,36 & 2 \\
\hline & Total Pertanyaan & 36 & \\
\hline
\end{tabular}

\section{Sumber: Data diolah}

\section{Uji Validitas dan Reliabilitas}

Uji validitas digunakan untuk menyatakan sejauh mana data yang didapatkan melalui instrumen penelitian akan mengukur apa yang ingin diukur. Sedangkan uji reliabilitas digunakan untuk menguji konsistensi alat pengukur yang digunakan dalam penelitian. Hasil uji validitas dan reliabilitas dapat dilihat pada tabel berikut:

Tabel 3. Uji Validitas dan Reliabilitas

\begin{tabular}{lcccc}
\hline \multirow{2}{*}{ Variabel } & \multicolumn{2}{c}{ Uji Validitas } & \multicolumn{2}{c}{ Uji Reliabilitas } \\
\cline { 2 - 5 } & $\begin{array}{c}\text { Rata-Rata } \\
\text { VIF }\end{array}$ & AVE & $\begin{array}{c}\text { Rata-Rata } \\
\text { Outer Weight }\end{array}$ & $\begin{array}{c}\text { Composite } \\
\text { Reliability }\end{array}$ \\
\hline Kepuasan Konsumen & & 0.533 & & 0.931 \\
\hline Kualitas Pelayanan & 3.469 & & 0.880 & 0.877 \\
\hline Lokasi & & 0.501 & & 0.932 \\
\hline Fasilitas & & 0.695 & &
\end{tabular}

\section{Sumber: Data diolah}

Berdasarkan tabel diatas, kualitas pelayanan memiliki nilai rata-rata $\mathrm{VIF}<5$ dan nilai Average Varian Extracted (AVE) $>0,50$, artinya bahwa instrumen yang digunakan dalam penelitian ini dinyatakan valid. Sedangkan untuk uji reliabilitas, kesadaran merek memiliki nilai rata-rata outer weight dan nilai composite reliability $>0,70$, artinya bahwa instrumen yang digunakan dinyatakan reliabel.

\section{Teknik Analisis Data}

Analisis data yang digunakan adalah analisis data deskriptif kuantitatif dengan menggunakan interval class statistic. Analisis ini digunakan untuk memberikan menggambarkan atau menganalisis suatu deskripsi data hasil yang dikumpulkan dalam penelitian. Analisis yang menggunakan data pada suatu kelompok agar dapat ditarik kesimpulannya (Sutopo \& Slamet, 2017, hlm. 2). Analisis deskriptif pada penelitian ini diperoleh dari jumlah jawaban responden menggunaan skala 1 sampai dengan 5 berdasarkan interval class statistics, berikut penjelasan mengenai skor tersebut :

$$
\begin{aligned}
& \mathbf{R} \text { (range) = Jumlah data terbesar }- \text { Jumlah data terkecil } \\
& =500-100=400 \\
& \text { K } \quad=1+3,33 \log \mathrm{N} \\
& \text { (Banyak kelas) } \quad=1+3,33 \log 100 \\
& \text { I } \quad=\mathrm{R} / \mathrm{K} \\
& =7,66 \text { (8 kelas) } \\
& \text { (Interval Class) } \quad=400 / 8 \\
& =50
\end{aligned}
$$

Tabel 3. Interpretasi Nilai Interval Class Responden

\begin{tabular}{cccc}
\hline Nilai $\underline{\text { Interval Class }}$ & Interpretasi & Nilai Interval Class & Interpretasi \\
\hline $450-500$ & Sangat Tinggi Sekali & $250-300$ & Cukup Tiggi \\
\hline $400-450$ & Sangat Tinggi & $200-250$ & Sedang \\
\hline $350-400$ & Tinggi & $150-200$ & Rendah \\
\hline $300-350$ & Agak Tinggi & $100-150$ & Sangat Rendah \\
\hline
\end{tabular}


Sunyi House of Coffee and Hope adalah coffee shop yang terletak di Jakarta selatan. Coffee shop ini mulai beroperasi pada tangga 3 April 2019 memiliki konsep yang unik yaitu memperkerjakan karyawan disabilitas. Pencetus coffee shop ini adalah Mario Gultom, sedangkan pemiliknya adalah Fernaldo Garcia disabi. Kata "Sunyi" memiliki arti yaitu "bukan tanpa suara tetapi sunyinya diskriminasi untuk kaum litas". Sunyi House of Coffee and Hope ini beralamat di J1. Rs Fatmawati No.14, Cilandak, Jakarta Selatan buka pada hari selasa-minggu, mulai pukul 10:00am - 22:00pm. Salah satu alasan berdirinya coffee shop ini adalah memberikan peluang bagi para penyandang disabilitas. Sunyi House of Coffee and Hope memiliki 5 karyawan yaitu 4 orang tunarungu dan tunawicara dan 1 orang tunadaksa. Dimana karyawan tersebut bekerja sebagai pelayanan, barista, chef dan kasir.

Komunikasi pada saat memesan antar pengunjung dan karyawan Sunyi House of Coffee and Hope menggunakan bahasa insyarat atau bisa juga langsung menunjuk menu produk mana yang akan dipilih. Sunyi House of Coffee and Hope menyediakan 23 menu minuman kopi atau non kopi dan 5 menu cemilan dan makanan utama. Salah satu menu minuman andalan adalah kopi susu sunyi yaitu kopi susu dengan base espresso ditambah susu yang menciptakan rasa yang tidak terlalu pahit. Sedangkan, untuk menu makanan andalan adalah spaghetti aglio-olio yang dimasak 'al dante' memiliki citra rasa yang gurih asin dengan irisan smoked beef. Selain menu tersebut, terdapat juga menu minuman lainnya seperti almond zist cold brew, dirty chai latte, red velvet latte hingga manual brew dari beberapa biji kopi lokal. Untuk makanannya ada ayam saus kecap wijen, cilantro lime chicken hingga french fries. Untuk harga yang di tawarkan oleh Sunyi House of Coffee and Hope sangat terjangkau yaitu sekitar Rp. 100.000 untuk 2 orang pelanggan.

Harapan untuk kedepannya pemilik Sunyi House of Coffee and Hope mengemukakan bahwa "tidak ada pandangan miring pada kaum penyandang disabilitas, tidak ada lagi memandang sebelah mata, dan tidak ada lagi mendiskriminasi kaum disabilitas. Kaum disabilitas bisa bersaing dengan kaum yang normal, mereka layak mendapatkan pekerjaan dan diperlakukan sama dengan masyarakat normal dan punya hak yang sama dengan kita" (Marison, 2019).

\section{Analisis Data Responden}

Dalam penelitian ini, data responden yang digunakan untuk memberikan gambaran deskripsi menurut domisili diwilayah Jakarta Selatan, jenis kelamin, usia, pekerjaan, jumlah pendapatan, berapa kali berkunjung dan berala lama dalam 1 kali kunjngan. Peneliti menyebarkan kuesioner kepada 100 responden. Berikut adalah deskripsi data konsumen yang pernah mengunjungi Sunyi House of Coffee and Hope.

Tabel 4. Karakteristik Responden Berdasarkan Domisili atau Tinggal di Wilayah Jakarta Selatan

\begin{tabular}{|c|c|c|}
\hline Karakteristik Responden & Frekuensi & Presentase \\
\hline Tinggal di Wilayah Jakarta Selatan & 49 & $49 \%$ \\
\hline Tidak Tinggal di Wilayah Jakarta Selatan & 44 & $44 \%$ \\
\hline Lainnya & 7 & $7 \%$ \\
\hline Jumlah & 100 & $100 \%$ \\
\hline
\end{tabular}

Sumber : Data Diolah

Disimpulkan pada tabel 4. bahwa sejumlah 49 yang menjadi responden dengan domisili Jakarta Selatan, kemudian 44 tinggal di wilayah Jakarta Timur, Jakarta Pusat dan Jakarta Utara. Dan sisanya sebanyak 7 merupakan domisili luar DKI Jakarta seperti di wilayah Depok, Tangerang Selatan dan Bogor. Jadi mayoritas pelanggan yang datang mengunjugi Sunyi House of Coffee and Hope adalah pelanggan yang berdomisili atau tinggal diwilayah Jakarta Setalan. Sementara pelanggan yang berdomisili atau tinggal di luar DKI Jakarta, seperti Depok, Tangerang dan Bogor lebih sedikit mengunjungi Sunyi House of Coffee and Hope. 
Customer

Satisfaction and

Coffee Shop
Tabel 5. Karakteristik Responden Berdasarkan Jenis Kelamin

\begin{tabular}{cccc}
\hline \multicolumn{2}{c}{ Karakteristik Responden } & Frekuensi & Presentase \\
\hline \multirow{2}{*}{ Jenis Kelamin } & Laki - Laki & 38 & $38 \%$ \\
\hline & Perempuan & 62 & $62 \%$ \\
\hline & Jumlah & 100 & $100 \%$
\end{tabular}

\section{Sumber: Data Diolah}

Disimpulkan pada tabel 5. bahwa sejumlah 38 orang responden teridetifikasi berjenis kelamin laki-laki kemudian sisanya berjenis kelamin wanita yaitu sebesar 62 orang. Artinya mayoritas pengunjung Sunyi House of Coffee and Hope ialah wanita.

\begin{tabular}{lccc}
\hline \multicolumn{2}{l}{ Karakteristik Responden } & Frekuensi & Presentase \\
\hline \multirow{4}{*}{ Usia } & $<17$ Tahun & 0 & $0 \%$ \\
\cline { 2 - 4 } & $18-23$ Tahun & 61 & $61 \%$ \\
\cline { 2 - 4 } & $24-29$ Tahun & 32 & $32 \%$ \\
\cline { 2 - 4 } & $>30$ Tahun & 7 & $7 \%$ \\
\hline & Jumlah & 100 & $100 \%$ \\
\hline
\end{tabular}

Sumber : Data Diolah

Disimpulkan pada tabel 6. bahwa jumlah pengunjung usia 17 tahun kebawah nihil, 61 diidentifikasi berusia 18 - 23 tahun, dan kemudian yang berusia $24-29$ tahun sebanyak 32, sisanya 7 diidentifikasi berusia diatas 30 tahun. Simpulannya pengunjung Sunyi House of Coffee and Hope mayoritas berusia 18 - 23 tahun.

Tabel 7. Karakteristik Responden Berdasarkan Pekerjaan

\begin{tabular}{cccc}
\hline \multirow{2}{*}{ Pekerjaan } & Karakteristik Responden & Frekuensi & Presentase \\
\cline { 2 - 4 } & Mahasiswa/Pelajar & 55 & $55 \%$ \\
\cline { 2 - 4 } & Karyawan Negeri/Swasta & 37 & $37 \%$ \\
\cline { 2 - 4 } & Wirausaha & 2 & $2 \%$ \\
\cline { 2 - 4 } & Lainnya & 6 & $6 \%$ \\
\hline & Jumlah & 100 & $100 \%$ \\
\hline
\end{tabular}

Sumber : Data Diolah

Disimpulkan pada tabel 7. bahwa jumlah pengunjung yang memiliki profesi mahasiswa/pelajar sebanyak 55, dengan perolehan 37 sebagai karyawan negeri/swasta, lalu responden dengan profesi sebagai wirausaha sebanyak 2 orang dengan presentase $2 \%$, dan responden dengan profesi lainnya sebanyak 6 orang atau dengan presentase $6 \%$. Yang dimaksud dengan profesi lainnya adalah seperti freelance, ibu rumah tangga, dan yang lainnya. Simpulan atas pengunjung mayoritas yang mengunjungi Sunyi House of Cofffe and Hope berprofesi mahasiswa atau pelajar.

Tabel 8. Karakteristik Responden Berdasarkan Pemasukan atau Uang Saku

\begin{tabular}{|c|c|c|c|}
\hline \multicolumn{2}{|c|}{ Karakteristik Responden } & Frekuensi & Presentase \\
\hline Pemasukan & $<$ Rp. 1.000 .000 & 26 & $26 \%$ \\
\hline \multirow{4}{*}{$\begin{array}{l}\text { atau Uang } \\
\text { Saku }\end{array}$} & Rp. $1.100 .000-$ Rp. 2.500 .000 & 33 & $33 \%$ \\
\hline & Rp. $2.600 .000-$ Rp. 3.500 .000 & 11 & $11 \%$ \\
\hline & > Rp. 3.600 .000 & 30 & $30 \%$ \\
\hline & Jumlah & 100 & $100 \%$ \\
\hline
\end{tabular}

\section{Sumber : Data Diolah}

Disimpulkan pada tabel 8 . bahwa sejumlah 26 responden yang memiliki pemasukan atau uang saku per bulannya dibawah Rp. 1.00.000. Kemudian 33 responden yang memiliki pemasukan atau uang saku per bulannya Rp. 1.100.000 - Rp. 2.500.000. Sementara 11 responden yang memiliki pemasukan atau uang saku per bulannya $R p$. $2.600 .000-3.500 .000$. Dan 30 responden yang memiliki pemasukan atau uang saku per bulannya diatas Rp. 3.600.000. disimpulkan mayoritas pelanggan Sunyi House of Coffee and Hope memiliki pemasukan per bulannya sebesar Rp. 1.000.000 - Rp. 2.500.000, dalam arti bahwa mayoritas pelanggan tersebut berprofesi mahasiswa atau pelajar dengan range umur sekitar $18-23$ tahun. 
Tabel 9. Karakteristik Responden Berdasarkan Kunjungan

\begin{tabular}{cccc}
\hline \multicolumn{2}{c}{ Karakteristik Responden } & Frekuensi & Presentase \\
\cline { 2 - 4 } Kunjungan & $<2 \mathrm{Kali}$ & 72 & $72 \%$ \\
\cline { 2 - 4 } & $3-4 \mathrm{Kali}$ & 21 & $21 \%$ \\
\cline { 2 - 4 } & $5-6 \mathrm{Kali}$ & 3 & $3 \%$ \\
\cline { 2 - 4 } & $7 \mathrm{Kali}$ & 4 & $4 \%$ \\
\hline & Jumlah & 100 & $100 \%$ \\
\hline
\end{tabular}

Sumber : Data Diolah

Disimpulkan pada tabel 9. bahwa jumlah responden yang bekunjung kurang dari 2 kali sebanyak 72 orrang atau $72 \%$, kemudian 21responden yang berkunjung 3 hingga 4 kali lalu 3responden dalam 5 sampai 6 kali kunjungan, sedangkan responden yang berkunjung 7 kali dalam seminggu sebanyak 4 orang. Maka, dapat disimpulkan bahwa pelanggan Sunyi House of Coffee and Hope yang berkunjung $<2$ kali dalam seminggu sebesar $72 \%$, dalam arti bahwa mayoritas pelanggan yang memiliki pekerjaan mahasiswa atau pelajar dengan rata-rata usia 18 - 23 tahun yang memiliki pemasukan per bulannya sebesar Rp.1.100.000 - Rp. 2.500.000.

Tabel 10. Karakteristik Responden Berdasarkan Lama Kunjungan

\begin{tabular}{cccc}
\hline \multicolumn{2}{c}{ Karakteristik Responden } & Frekuensi & Presentase \\
\hline \multirow{2}{*}{ Lama Kunjungan } & $<2$ Jam & 43 & $43 \%$ \\
\cline { 2 - 4 } & 3-4 Jam & 40 & $40 \%$ \\
\cline { 2 - 4 } & $5-6$ Jam & 7 & $7 \%$ \\
\cline { 2 - 4 } & $>$ 7 Jam & 10 & $10 \%$ \\
\hline
\end{tabular}

\section{Sumber : Data Diolah}

Disimpulkan pada tabel 10. bahwa jumlah responden yang berkunjung kurang dari 2 jam sebanyak 43 orang, sementara responden yang berkunjung $3-4$ jam sebanyak 40 orang, kemudian responden yang berkunjung 5-6 jam sebanyak 7 orang, dan responden yang berkunjung lebih dari 7 jam sebanyak 10 orang. Hal ini dapat disimpulkan bahwa pelanggan Sunyi House of Coffee and Hope yang berkunjung kurang dari 2 jam dalam satu kali kunjungan sebesar $43 \%$ atau 43 orang. Dalam arti bahwa mayoritas pelanggan Sunyi House of Coffee and Hope yang memiliki pekerjaan mahasiswa atau pelajar dengan rata-rata usia 18 - 23 tahun yang memiliki pemasukan per bulannya sebesar Rp.1.100.000 - Rp. 2.500.000 dan sering berkunjung kurang dari 2 kali dalam seminggu.

\section{Analisis Jawaban Responden Terhadap Variabel Kepuasan Konsumen}

Berikut ini adalah hasil jawaban responden terhadap variabel kepuasan konsumen berdasarkan nilai intervalnya.

Tabel 11. Hasil Tanggapan Responden Terhadap Variabel Kepuasan Konsumen

\begin{tabular}{|c|c|c|c|c|c|c|c|c|c|c|c|}
\hline \multirow{4}{*}{$\begin{array}{l}\text { Kepuasan } \\
\text { Konsumen }\end{array}$} & \multicolumn{10}{|c|}{ Jawaban Responden } & \multirow{4}{*}{ Interval } \\
\hline & \multirow{2}{*}{\multicolumn{2}{|c|}{$\begin{array}{c}\text { STM } \\
1 \\
\end{array}$}} & \multirow{2}{*}{\multicolumn{2}{|c|}{$\begin{array}{c}\text { TM } \\
2 \\
\end{array}$}} & \multirow{2}{*}{\multicolumn{2}{|c|}{$\begin{array}{c}\mathrm{N} \\
3\end{array}$}} & \multirow{2}{*}{\multicolumn{2}{|c|}{$\begin{array}{c}M \\
4 \\
\end{array}$}} & \multirow{2}{*}{\multicolumn{2}{|c|}{$\begin{array}{c}\mathrm{SM} \\
5 \\
\end{array}$}} & \\
\hline & & & & & & & & & & & \\
\hline & $\mathrm{F}$ & $\%$ & $\mathrm{~F}$ & $\%$ & $\mathrm{~F}$ & $\%$ & $\mathrm{~F}$ & $\%$ & $\mathrm{~F}$ & $\%$ & \\
\hline KK1 & 1 & 1.00 & 0 & 0.00 & 8 & 8.00 & 52 & 52.00 & 39 & 39.00 & 428 \\
\hline KK2 & 1 & 1.00 & 0 & 0.00 & 13 & 13.00 & 45 & 45.00 & 41 & 41.00 & 425 \\
\hline KK3 & 1 & 1.00 & 1 & 1.00 & 4 & 4.00 & 36 & 36.00 & 58 & 58.00 & 449 \\
\hline KK4 & 1 & 1.00 & $\mathbf{0}$ & 0.00 & 3 & 3.00 & 32 & 32.00 & 64 & 64.00 & 458 \\
\hline KK5 & 1 & 1.00 & 0 & 0.00 & 10 & 10.00 & 32 & 32.00 & 57 & 57.00 & 444 \\
\hline KK6 & 0 & 0.00 & 3 & 3.00 & 24 & 24.00 & 34 & 34.00 & 39 & 39.00 & 409 \\
\hline KK7 & 0 & 0.00 & 8 & 8.00 & 36 & 36.00 & 32 & 32.00 & 24 & 24.00 & 372 \\
\hline KK8 & 0 & 0.00 & 0 & 0.00 & 14 & 14.00 & 49 & 49.00 & 37 & 37.00 & 423 \\
\hline KK9 & 0 & 0.00 & 4 & 4.00 & 23 & 23.00 & 38 & 38.00 & 35 & 35.00 & 404 \\
\hline KK10 & 0 & 0.00 & 1 & 1.00 & 7 & 7.00 & 37 & 37.00 & 55 & 55.00 & 446 \\
\hline KK11 & 0 & 0.00 & 2 & 2.00 & 9 & 9.00 & 37 & 37.00 & 52 & 52.00 & 439 \\
\hline KK12 & 0 & 0.00 & 1 & 1.00 & 6 & 6.00 & 49 & 49.00 & 44 & 44.00 & 436 \\
\hline \multicolumn{11}{|c|}{ Rata - Rata Total Interval } & 427.75 \\
\hline
\end{tabular}

\section{Sumber: Data Diolah}

Berdasarkan data pada tabel diatas bahwa nilai interval tertinggi terdapat pada butir pernyataan KK4 yaitu sebesar 458, sehingga dapat diartikan bahwa konsumen merasa puas terhadap perilaku karyawan yang sopan kepada konsumen pada saat melayani.
Satisfaction and

Coffee Shop

255 
Customer

Satisfaction and

Coffee Shop

Sedangkan, nilai interval terendah terdapat pada butir pernyataan KK7 yaitu sebesar 372, sehingga dapat diartikan puanya konsumen dengan lalu-lintas yang ramai lancer dan lalulintas tidak rawan kemacetan. Walaupun KK7 termasuk nilai indeks terendah diantara instrumen pernyataan pada variabel kepuasan konsumen, hal ini menandakan bahwa lalu-lintas (traffic) Sunyi House of Coffee and Hope sudah sesuai dengan harapan konsumen.

Sementara, untuk rata-rata indeks skor jawaban variabel kepuasan konsumen diperoleh sebesar 427,75, dengan hasil tersebut termasuk dalam kategori nilai interval sangat tinggi yang berarti bahwa tingkat kepuasan konsumen terhadap Sunyi House of Coffee and Hope juga tinggi. Maka dapat disimpulan bahwa kepuasan konsumen terhadap Sunyi House of Cofffe and Hope sangat baik.

Analisis Jawaban Responden Terhadap Variabel Kualitas Pelayanan

Berikut ini adalah hasil jawaban responden terhadap variabel kualitas pelayanan berdasarkan nilai intervalnya.

Tabel 12. Hasil Tanggapan Responden Terhadap Variabel Kualitas Pelayanan

\begin{tabular}{|c|c|c|c|c|c|c|c|c|c|c|c|}
\hline \multirow{4}{*}{$\begin{array}{l}\text { Kualitas } \\
\text { Pelayanan }\end{array}$} & \multicolumn{10}{|c|}{ Jawaban Responden } & \multirow{4}{*}{ Interval } \\
\hline & \multirow{2}{*}{\multicolumn{2}{|c|}{$\begin{array}{c}\text { STS } \\
1\end{array}$}} & \multirow{2}{*}{\multicolumn{2}{|c|}{$\begin{array}{c}\text { TS } \\
2\end{array}$}} & \multirow{2}{*}{\multicolumn{2}{|c|}{$\begin{array}{l}\mathrm{N} \\
3\end{array}$}} & \multirow{2}{*}{\multicolumn{2}{|c|}{$\begin{array}{l}\mathrm{S} \\
4\end{array}$}} & \multirow{2}{*}{\multicolumn{2}{|c|}{$\begin{array}{c}\text { SS } \\
5\end{array}$}} & \\
\hline & & & & & & & & & & & \\
\hline & $\mathrm{F}$ & $\%$ & $\mathrm{~F}$ & $\%$ & $\mathrm{~F}$ & $\%$ & $\mathrm{~F}$ & $\%$ & $\mathrm{~F}$ & $\%$ & \\
\hline KP13 & 1 & 1.00 & 0 & 0.00 & 5 & 5.00 & 40 & 40.00 & 54 & 54.00 & 446 \\
\hline KP14 & 1 & 1.00 & 0 & 0.00 & 4 & 4.00 & 37 & 37.00 & 58 & 58.00 & 451 \\
\hline KP15 & 0 & 0.00 & 2 & 2.00 & 7 & 7.00 & 42 & 42.00 & 49 & 49.00 & 438 \\
\hline KP16 & 0 & 0.00 & 2 & 2.00 & 11 & 11.00 & 44 & 44.00 & 43 & 43.00 & 428 \\
\hline KP17 & 1 & 1.00 & 1 & 1.00 & 14 & 14.00 & 46 & 46.00 & 38 & 38.00 & 419 \\
\hline KP18 & 1 & 1.00 & 0 & 0.00 & 8 & 8.00 & 47 & 47.00 & 44 & 44.00 & 433 \\
\hline KP19 & 1 & 1.00 & $\mathbf{0}$ & 0.00 & 3 & 3.00 & 31 & 31.00 & 65 & 65.00 & 459 \\
\hline KP20 & 1 & 1.00 & 0 & 0.00 & 4 & 4.00 & 45 & 45.00 & 50 & 50.00 & 443 \\
\hline KP21 & 1 & 1.00 & 1 & 1.00 & 11 & 11.00 & 39 & 39.00 & 48 & 48.00 & 432 \\
\hline KP22 & 1 & 1.00 & 0 & 0.00 & 5 & 5.00 & 41 & 41.00 & 53 & 53.00 & 445 \\
\hline & & & Rat & Rata & & terval & & & & & 439.4 \\
\hline
\end{tabular}

Sumber : Data Diolah

Berdasarkan data pada tabel diatas bahwa nilai interval tertinggi terdapat pada butir pernyataan KP19 yaitu sebesar 459, sehingga dapat diartikan bahwa karyawan Sunyi House of Coffee and Hope berperilaku sopan dan ramah kepada setiap pelanggan yang berkunjung. Sedangkan, nilai interval terendah terdapat pada butir pernyataan KK17 yaitu sebesar 419, sehingga dapat diartikan bahwa karyawan menerima pesanan dan memproses pesanan dengan cepat yang membuat konsumen tidak menunggu lama untuk memesan maupun menerima pesanan. Meskipun KP17 termasuk nilai interval terendah diantara instrumen pernyataan pada variabel kualitas pelayanan, hal ini menandakan bahwa karyawan melayani pesanan konsumen dengan baik dan cepat.

Sementara, untuk rata-rata interval skor jawaban variabel kualitas pelayanan diperoleh sebesar 439,4, dengan hasil tersebut termasuk dalam kategori nilai interval sangat tinggi yang berarti bahwa tingkat kualitas pelayanan terhadap Sunyi House of Coffee and Hope juga tinggi. Maka dapat disimpulkan bahwa kualitas pelayanan yang diberikan oleh Sunyi House of Coffee and Hope kepada konsumen telah memberian kesan yang positif dan sangat baik.

\section{Analisis Jawaban Responden Terhadap Variabel Lokasi}

Berikut ini adalah hasil jawaban responden terhadap variabel lokasi berdasarkan nilai intervalnya sebagaimana Tabel 13. Berdasarkan data pada tabel 13 bahwa nilai interval tertinggi terdapat pada butir pernyataan L26 yaitu sebesar 449, sehingga dapat diartikan bahwa kondisi lalu-lintas yang ramai namun lancar yang ditawarkan oleh Sunyi House of Coffee and Hope dimana pada kondisi tersebut membuat pelanggan selalu mengunjunginya. Sedangkan, nilai interval terendah terdapat pada butir pernyataan L25 yaitu sebesar 413, sehingga dapat diartikan bahwa kondisi daerah Sunyi House of Coffee and Hope yang tidak rawan kemacetan. Meskipun L25 termasuk nilai interval terendah diantara instrumen pernyataan pada variabel lokasi, hal ini menandakan pelanggan setuju 
jika daerah yang ditawarkan oleh Sunyi House of Coffee and Hope bukanlah daerah yang macet dan dapat dijangkau oleh konsumen.

Tabel 13. Hasil Tanggapan Responden Terhadap Variabel Lokasi

\begin{tabular}{|c|c|c|c|c|c|c|c|c|c|c|c|}
\hline \multirow{3}{*}{ Lokasi } & \multicolumn{10}{|c|}{ Jawaban Responden } & \multirow{3}{*}{ Interval } \\
\hline & \multicolumn{2}{|c|}{$\begin{array}{c}\text { STS } \\
1\end{array}$} & \multicolumn{2}{|c|}{$\begin{array}{c}\text { TS } \\
2\end{array}$} & \multicolumn{2}{|c|}{$\begin{array}{c}\mathrm{N} \\
3\end{array}$} & \multicolumn{2}{|c|}{$\begin{array}{l}S \\
4\end{array}$} & \multicolumn{2}{|c|}{$\begin{array}{c}\text { SS } \\
5\end{array}$} & \\
\hline & $\mathrm{F}$ & $\%$ & $\mathrm{~F}$ & $\%$ & $\mathrm{~F}$ & $\%$ & $\mathrm{~F}$ & $\%$ & $\mathrm{~F}$ & $\%$ & \\
\hline $\mathrm{L} 23$ & 1 & 1.00 & 2 & 2.00 & 17 & 17.00 & 38 & 38.00 & 42 & 42.00 & 418 \\
\hline L24 & 0 & 0.00 & 1 & 1.00 & 12 & 12.00 & 39 & 39.00 & 48 & 48.00 & 434 \\
\hline L25 & 1 & 1.00 & 1 & 1.00 & 17 & 17.00 & 46 & 46.00 & 35 & 35.00 & 413 \\
\hline L26 & 1 & 1.00 & $\mathbf{0}$ & 0.00 & 7 & 7.00 & 33 & 33.00 & 59 & 59.00 & 449 \\
\hline L27 & 1 & 1.00 & 0 & 0.00 & 8 & 8.00 & 42 & 42.00 & 49 & 49.00 & 438 \\
\hline L28 & 1 & 1.00 & 0 & 0.00 & 6 & 6.00 & 39 & 39.00 & 54 & 54.00 & 445 \\
\hline L29 & 0 & 0.00 & 4 & 4.00 & 17 & 17.00 & 30 & 30.00 & 40 & 40.00 & 415 \\
\hline L30 & 1 & 1.00 & 0 & 0.00 & 9 & 9.00 & 36 & 36.00 & 54 & 54.00 & 436 \\
\hline \multicolumn{11}{|c|}{ Rata - Rata Total Interval } & 431 \\
\hline
\end{tabular}

\section{Sumber : Data Diolah}

Sementara, untuk rata-rata interval skor jawaban variabel lokasi diperoleh sebesar 431, dengan hasil tersebut termasuk dalam kategori nilai interval sangat tinggi sekali yang berarti bahwa tingkat lokasi terhadap Sunyi House of Coffee and Hope juga tinggi. Maka dapat disimpulkan bahwa Sunyi House of Coffee and Hope telah memilih lokasi yang strategis dan tepat agar mudah ditemukan oleh pelanggan

\section{Analisis Jawaban Responden Terhadap Variabel Fasilitas}

Berikut ini adalah hasil jawaban responden terhadap variabel fasilitas berdasarkan nilai intervalnya.

Tabel 14. Hasil Tanggapan Responden Terhadap Variabel Fasilitas

\begin{tabular}{|c|c|c|c|c|c|c|c|c|c|c|c|}
\hline \multirow{4}{*}{ Fasilitas } & \multicolumn{10}{|c|}{ Jawaban Responden } & \multirow{4}{*}{ Interval } \\
\hline & \multirow{2}{*}{\multicolumn{2}{|c|}{$\begin{array}{c}\text { STS } \\
1\end{array}$}} & \multirow{2}{*}{\multicolumn{2}{|c|}{$\begin{array}{c}\mathrm{TS} \\
2\end{array}$}} & \multirow{2}{*}{\multicolumn{2}{|c|}{$\begin{array}{l}\mathrm{N} \\
3 \\
\end{array}$}} & \multirow{2}{*}{\multicolumn{2}{|c|}{$\begin{array}{l}S \\
4 \\
\end{array}$}} & \multirow{2}{*}{\multicolumn{2}{|c|}{$\begin{array}{c}\text { SS } \\
5\end{array}$}} & \\
\hline & $\mathrm{F}$ & & & & & & & & & & \\
\hline & & $\%$ & $\mathrm{~F}$ & $\%$ & $\mathrm{~F}$ & $\%$ & $\mathrm{~F}$ & $\%$ & $\mathrm{~F}$ & $\%$ & \\
\hline F31 & 1 & 1.00 & $\mathbf{0}$ & 0.00 & 5 & 5.00 & 36 & 36.00 & 58 & 58.00 & 450 \\
\hline F32 & 0 & 0.00 & 2 & 2.00 & 8 & 8.00 & 33 & 33.00 & 57 & 57.00 & 445 \\
\hline F33 & 0 & 0.00 & 2 & 2.00 & 11 & 11.00 & 39 & 39.00 & 48 & 48.00 & 433 \\
\hline F34 & 1 & 1.00 & 0 & 0.00 & 4 & 4.00 & 43 & 43.00 & 52 & 52.00 & 445 \\
\hline F35 & $\mathbf{0}$ & 0.00 & 2 & 2.00 & 12 & 12.00 & 40 & 40.00 & 46 & $46 . .00$ & 430 \\
\hline F36 & 0 & 0.00 & 2 & 2.00 & 11 & 11.00 & 41 & 41.00 & 46 & 46.00 & 431 \\
\hline \multicolumn{11}{|c|}{ Rata - Rata Total Interval } & 439 \\
\hline
\end{tabular}

\section{Sumber: Data Diolah}

Berdasarkan data pada tabel diatas bahwa nilai interval tertinggi terdapat pada butir pernyataan F31 yaitu sebesar 450, , sehingga dapat diartikan bahwa penataan ruangan yang baik dan rapi yang di tawarkan oleh Sunyi House of Coffee and Hope, baik itu penataan meja, kursi, lukisan dll. Sedangkan, nilai interval terendah terdapat pada butir pernyataan F35 yaitu sebesar 430, sehingga dapat diartikan bahwa penerangan lampu yang di tawarkan Sunyi House of Coffee and Hope membuat pelanggan yang berkunjung merasa nyaman dan suka berlama-lama di coffee shop tersebut. Meskipun F35 termasuk nilai interval terendah diantara instrumen pernyataan pada variabel fasilitas hal ini menandakan bahwa pelanggan sangat setuju jika kondisi penerangan lampu yang baik sudah di berikan oleh Sunyi House of Coffee and Hope terhadap konsumen.

Sementara, untuk rata-rata interval skor jawaban variabel fasilitas diperoleh sebesar 439, dengan hasil tersebut termasuk dalam kategori nilai interval sangat tinggi yang berarti bahwa tingkat fasilitas terhadap Sunyi House of Coffee and Hope juga tinggi. Maka dapat disimpulan bahwa fasilitas yang telah disediakan oleh Sunyi House of Coffee dapat memberikan kenyamanan sesuai dengan kebutuhan dan keinginan pelanggan.

\section{Kualitas Pelayanan, Lokasi, Fasilitas dan Kepuasan Konsumen}

Hasil rata-rata indeks skor jawaban variabel kepuasan konsumen berada di kategori nilai interval sangat tinggi dalam arti jika tingkat kepuasan konsumen terhadap Sunyi House of Coffee and Hope sudah sangat kuat dan mampu untuk memunculkan perasaan senang dan puas dari konsumen tersebut. Sedangkan, hasil rata-rata interval skor jawaban
Satisfaction and Coffee Shop 
Customer

Satisfaction and

Coffee Shop

variabel kualitas pelayanan dan fasilitas berada pada kategori nilai interval sangat tinggi dalam arti kualitas pelayanan dan fasilitas yang telah diberikan oleh Sunyi House of Coffee and Hope sudah sangat baik, dimana pelayanan yang diterima oleh konsumen dan kondisi fasilitas yang membuat nyaman konsumen saat di coffee shop tersbut. Serta, hasil rata-rata interval skor jawaban variabel lokasi berada dalam kategori sangat tinggi sekali dalam arti bahwa kondisi lokasi yang ditawarkan oleh Sunyi House of Coffee and Hope membuat konsumen merasa telah dipenuhinya keinginan dan kebutuhan konsumen tersebut. Jika dilihat dari indikator kualitas pelayanan yang digunakan yaitu karyawan berpenampilan baik dan rapih, karyawan tepat dalam memberikan informasi, karyawan yang cepat tanggap dalam pelayanan, karyawan bersikap sopan pada saat melayani konsumen, dan Karyawan memahami apa yang diinginkan konsumen, konsumen menilai hal tersebut yang menimbulkan suatu keinginan untuk kembali lagi mengunjungi Sunyi House of Coffee and Hope. Kemudian, lokasi di nilai baik oleh konsumen karena penempatan yang strategis dan mudah dijangkau oleh konsumen. Lalu, konsumen menilai bahwa fasilitas yang disediakan oleh Sunyi House of Coffee and Hope sangat sesuai dengan konsep coffee shop tersebut. Hal tersebut sejalan dengan penelitian yang dilakukan (Adhistyo W \& Nugraheni, 2020; Mahyuddin \& Juraidah, 2017).

\section{PENUTUP}

Berdasarkan penelitian dan analisis data yang diperoleh mengenai kepuasan konsumen Sunyi House of Coffee and Hope, maka dapat ditarik kesimpulan yaitu

1. Hasil pada penelitian menunjukkan bahwa pelanggan yang pernah berkunjung ke Sunyi House of Coffee and Hope adalah mereka yang berdomisili atau bertempat tinggal di Jakarta Selatan dimana sebagian besarnya berjenis kelamin perempuan dengan usia sekitar 18-23 tahun yang berprofesi sebagai mahasiswa/pelajar serta pemasukan atau uang saku setiap bulannya sebesar Rp 1.100 .000 - Rp. 2.500.000. Sementara pelanggan yang berkunjung kurang dari 2 kali dalam seminggu dan menghabiskan waktu sekitar 2 jam dalam satu kali kunjungan di Sunyi House of Coffee and Hope.

2. Hasil dari analisis deskriptif menggunakan interval class ternyata pelanggan Sunyi House of Coffee and Hope ini mempersepsikan bahwa kepuasan konsumen yang diberikan kepada pelanggan sangat tinggi. Sehingga pelanggan menilai bahwa kunjungannya diluar ekspetasi yang diharapkan. Maka dapat dilihat dari variabel kepuasan konsumen terhadap Sunyi House of Cofffe and Hope sangat baik.

3. Sementara, hasil dari analisis deskriptif menggunakan interval class ternyata pelanggan Sunyi House of Coffee and Hope ini mempersepsikan bahwa kualitas pelayanan yang diberikan kepada pelanggan lebih tinggi. Sehingga pelanggan tidak perlu khawatir mengenai pelayanan yang akan diberikan, maka dapat dilihat dari variabel kualitas pelayanan.

4. Lalu, hasil dari analisis deskriptif menggunakan interval class ternyata pelanggan Sunyi House of Coffee and Hope ini mempersepsikan bahwa lokasi yang ditawarkan kepada pelanggan juga sangat tinggi. Sehingga pelanggan dengan mudah menemukan lokasi Sunyi House of Coffee and Hope karena penempatan lokasi yang strategis. Maka dapat dilihat dari variabel lokasi.

5. Kemudian, hasil dari analisis deskriptif menggunakan interval class ternyata pelanggan Sunyi House of Coffee and Hope ini mempersepsikan bahwa fasilitas yang ditawarkan kepada pelanggan juga tinggi. Sehingga pelanggan nyaman saat berada di Sunyi House of Coffee and Hope, maka dapat dilihat dari variabel fasilitas.

Adapun keterbatasan penelitian ini adalah peneliti mengalami keterhambatan dalam melakukan penyebaran kuesioner, dikarenakan adanya wabah penyakit Covid-19 dan pemberlakuan PSBB di Indonesia khususnya di wilayah DKI Jakarta yang menyebabkan coffee shop Sunyi House of Coffee and Hope sementara ini hanya menerima pesanan secara online atau takeaway. Perolehan kuesioner lewat google form mengalami kesulitan sebab tentuan target responden adalah responden yang pernah mengunjungi Sunyi House of 
Coffee and Hope, maka peneliti harus menghubungi satu persatu pelanggan yang pernah mengunjungi Sunyi House of Coffee and Hope, namun terdapat pelanggan yang tidak merespon dan tidak ingin mengisi kuesioner tersebut. Kemudian, 115 jawaban responden diperolah dari pelanggan Sunyi House of Coffee and Hope, kemudian beberapa dieliminasi yang sesuai dengan tentuan kriteria sebanyak 100.

\section{DAFTAR PUSTAKA}

[1] Abdullah, T., \& Tantri, F. (2018). Manajemen Pemasaran (Ed.7). Depok: PT RajaGrafindo Persada.

[2] Adhistyo W, T., \& Nugraheni, K. S. (2020). Studi Kepuasan Konsumen Pada Peacock Coffee Gajah Mada Semarang. Jurnal Riset Inspirasi Manajemen Dan Kewirausahaan, 4(1), 38-48. https://doi.org/10.35130/jrimk.v4i1.79

[3] Apriyani, D. A., \& Sunarti. (2017). Pengaruh Kualitas Layanan Terhadap Kepuasan Konsumen. Jurnal Manajemen Dan Bisnis Sriwijaya, 11(4), 301-318.

[4] Arifin, H. S. (2019). Pemasaran Era Milenium (Ed.1). Yogyakarta: Deepublish.

[5] Asniwaty, B., Sehe, M., Siswanto, B., \& Satryawati, -. (2019). Analysis of Effect of Service Quality, Physical Environment And Customer Experience To Customer Loyalty Through Customer Satisfaction of Visitor Starbucks Coffee In Samarinda. 75(ICMEMm 2018), 122-128. https://doi.org/10.2991/icmemm-18.2019.7

[6] Dewa, C. B. (2019). Pengaruh Kualitas Restoran Terhadap Kepuasan Pelanggan Cengkir Heritage Resto And Coffe. Khasanah Ilmu - Jurnal Pariwisata Dan Budaya, 10(1). https://doi.org/10.31294/khi.v10i1.5639

[7] Hadiguna, R. A., \& Setiawan, H. (2008). Tata Letak Pabrik (Ed.1). Yogyakarta: ANDI.

[8] Irvanto, O. and Sujana, S., 2020. Pengaruh Desain Produk, Pengetahuan Produk, Dan Kesadaran Merek Terhadap Minat Beli Produk Eiger. Jurnal Ilmiah Manajemen Kesatuan, 8(2), pp.105-126.

[9] Jufriyanto, M. (2020). Analisis Tingkat Kepuasan Konsumen Pada Kualitas Pelayanan Kedai Kopi Shelter. Matrik, XX(2), 79-90. https://doi.org/10.350587/Matrik

[10] Kasmir, D. (2017). Customer Services Excellent (Ed.1). Jakarta: PT RajaGrafindo Persada.

[11] Kementan. (2014). Renstra Kementrian Pertanian Pertanian Tahun 2015 - 2019. In Hari Aids Sedunia 2014 (pp. 1-339). https://doi.org/351.077 Ind r

[12] Limbeng, I. P., Lapian, S. L. H. V. J., Loindong, S. S. R., Ekonomi, F., Manajemen, J., \& Ratulangi, U. S. (2020). PENGARUH STORE LOCATION TERHADAP LOYALITAS DAN KEPUASAN KONSUMEN PADA WHAT'S UP MANADO THE EFFECT OF STORE LOCATION ON LOYALTY AND CONSUMER SATISFACTION IN WHAT' S UP MANADO. 8(1), 262-271.

[13] Mahyuddin, T., \& Juraidah, J. (2017). Analisis Pengaruh Kualitas Produk, Pelayanan Dan Lokasi Terhadap Kepuasan Pengunjung Warung Kopi One Love Di Kota Kuala Simpang. Jurnal Penelitian Agrisamudra, 2(1), 81-90. https://doi.org/10.33059/jpas.v2i1.238

[14] Marison, M. (2019). Menikmati Uniknya Sunyi House of Coffee and Hope, Kafe Dari dan Untuk Penyandang Disabilitas. Megapolitan.kompas.com. 20-07-2019.

[15] Mu'tashim, M. I., \& Slamet, A. S. (2020). Pengaruh Kualitas Produk dan Kualitas Pelayanan terhadap Kepuasan Konsumen (Studi Kasus Pada Coffee Shop di Kota Bogor). Jurnal Manajemen Dan Organisasi, 10(2), 118-132. https://doi.org/10.29244/jmo.v10i2.30131

[16] Mulyana, M., 2012. Consumer Behaviour: Sukses Dengan Memahami Konsumen.

[17] Pantilu, D., Koleangan, R. A. M., \& Roring, F. (2018). Pengaruh Kualitas Pelayanan, Harga Dan Fasilitas Terhadap Kepuasan Pelanggan Pada Warunk Bendito Kawasan Megamas Manado. Jurnal EMBA: Jurnal Riset Ekonomi, Manajemen, Bisnis Dan Akuntansi, 6(4), 3723-3732.
Satisfaction and Coffee Shop 
Customer

Satisfaction and

Coffee Shop

\section{0}

https://doi.org/10.35794/emba.v6i4.21898

[18] Putri, V. D. A., \& Suasana, I. G. A. K. G. (2017). PENGARUH ELEMEN EKUITAS MEREK TERHADAP KEPUTUSAN PEMBELIAN DI GERAI STARBUCKS COFFEE (Studi Pada Konsumen Domestik Starbucks Coffee di Wilayah Bali). E-Jurnal Manajemen Universitas Udayana, 7(1), 470. https://doi.org/10.24843/ejmunud.2018.v7.i01.p18

[19] Ratnasari, R. T., \& Aksa, M. H. (2016). Manajemen Pemasaran Jasa - Teori dan Kasus (R. Sikumbang (ed.); Ed.2). Bogor: Ghalia Indonesia.

[20] Sangadji, E. M., \& Sopiah, D. (2013). Perilaku Konsumen - Pendekatan Praktis Disertai Himpunan Jurnal Penelitian (N. WK (ed.)). Yogyakarta: ANDI.

[21] Soebiakto, B. (2018). Alasan Generasi Milenial Lebih Konsumtif. Cnnindonesia.Com. https://www.cnnindonesia.com/gaya-hidup/20180418215055-282-291845/alasangenerasi-milenial-lebih-konsumtif

[22] Sofia, A., Pangaribuan, C. H., \& Sitinjak, M. F. (2019). Factors of Coffee Shop Revisit Intention and Word-of-Mouth Mediated By Customer Satisfaction. Journal of Management and Business, 19(1). https://doi.org/10.24123/jmb.v19i1.418

[23] Sugianto, D. (2019). Hasil Riset: Kedai Kopi di RI Bertambah 2.000 Dalam 3 Tahun. Finance.Detik.Com. https://finance.detik.com/berita-ekonomi-bisnis/d4826275/hasil-riset-kedai-kopi-di-ri-bertambah-2000-dalam-3-tahun

[24] Sugiyono, P. D. (2014a). Metode Penelitian Kombinasi (Mixed Methods) (Sutopo (ed.)). Alfabeta, CV.

[25] Sugiyono, P. D. (2014b). Metode Penelitian Manajamen (Setiyawami (ed.)). Bandung: Alfabeta, CV.

[26] Sulistiono, S., Fadillah, A. and Putrie, D.E., 2020, May. Factors Affecting Bogor Botanical Garden Visitors' Intention Before and After the One Way System Application. In 2nd International Seminar on Business, Economics, Social Science and Technology (ISBEST 2019) (pp. 291-296). Atlantis Press.

[27] Sutopo, D. E. Y., \& Slamet, P. D. A. (2017). Statistika Inferensial (Giovanny (ed.); Ed.1). Yogyakarta: ANDI.

[28] Theisen, D. M., \& Metzner, B. (2018). The Asia Pacific PENGARUH KUALITAS PRODUK DAN KUALITAS PELAYANAN TERHADAP KEPUASAN KONSUMEN PADA CAFE DEUMDEE RANGKASBITUNG. Pharmazeutische Industrie, 80(3), 391-397. https://doi.org/10.4324/9781315468891-39

[29] Tjiptono, F., \& Chandra, G. (2016). Service Quality dan Satisfaction (Ed.4). Yogyakarta: ANDI.

[30] Utami, R. (2018). Fenomena "Coffee Shop" sebagai Tempat Nongkrong Kawula Mud. Www.Kompasiana.Com.

https://www.kompasiana.com/rieska55343/5bf18a37aeebe14f0d778b15/fenomen a-coffee-shop-sebagai-tempat-nongkrong-baru-kawula-muda

[31] Wibowo, A. H., \& Fausi, M. (2107). Pelayanan Konsumen (Ed.I). Yogyakarta: Parama Publishing.

[32] Winarno, S., Mananeke, L., \& Ogi, I. W. J. (2018). Konsumen Kedai Kopi Maxx Coffee Cabang Hotel Aryaduta Manado Analysis Consumer Services and Facilities To Customer Satisfaction the. Jurnal EMBA, 6(3), 1248-1257. file:///C:/Users/User-PC/Downloads/20181-42045-1-PB.pdf

[33] Yunita, M. (2018). PENGARUH PELAYANAN DAN KUALITAS PRODUK TERHADAP KEPUASAN KONSUMEN KOPICIE JALAN GATOT SUBROTO KOTA MEDAN. 6(1), 13-21.

[34] Zeithaml, V. A., Bitner, M. J., \& Gremler, D. D. (2006). Service Marketing - Integrating Customer Focus Across the Firm. Singapore: McGraw-Hill.

[35] Zuhdi, S., Rainanto, B.H. and Apriyani, D., 2020, May. Analysis of Co-Branding Strategy to Improve Company's Competitive Power (Case Study on Walls Selection Oreo). In 2nd International Seminar on Business, Economics, Social Science and Technology (ISBEST 2019) (pp. 146-149). Atlantis Press. 